\title{
STUDENTS OF THE UNIVERSITY OF SZGZECIN AS CANDIDATES FOR THE OLYMPIC OR PARALYMPIC GAMES TOKYO 2020
}

\author{
Jerzy Eider \\ University of Szczecin, Faculty of Physical Culture and Health Promotion, Poland \\ Address for correspondence: \\ Jerzy Eider \\ University of Szczecin, Faculty of Physical Education and Health Promotion \\ Al. Piastów 40b, building 6, 71-065 Szczecin, Poland \\ E-mail:jerzy.eider@usz.edu.pl
}

\begin{abstract}
Ahstract Balancing sports practice at the highest world level with university education is a difficult - but feasible - task. An example of such skilful balance are some graduates of the Higher Pedagogical School in Szczecin, University of Szczecin, majoring in Physical Education, who graduated from the university with a successfully defended Master's thesis while being active athletes.

The aim of this paper is: to present current students of the Faculty of Physical Culture and Health Promotion of the University of Szczecin (WKFiPZ US) and a graduate of the Institute of Physical Culture of the Faculty of Natural Sciences at the University of Szczecin (IKF WNP US) as potential candidates of various disciplines for the $32^{\text {nd }}$ Summer Olympic or $16^{\text {th }}$ Paralympic Games Tokyo 2020; to show their sports achievements in previous Olympic and Paralympic Games; to present the indicators and qualification rules that the analysed athletes must follow to represent Poland in the Olympic and Paralympic Games Tokyo 2020. The study involved a group of seven athletes, current students of the University of Szczecin, Faculty of Physical Culture and Health Promotion: Patryk Dobek, Michał Gadowski, Marcin Lewandowski, Piotr Lisek, Katarzyna Mądrowska, Paulina Woźniak, Krystian Zalewski and one graduate of the Institute of Physical Culture of the Faculty of Natural Sciences of the University of Szczecin, Anna Harkowska. All of them are members of the national Polish team in their respective sport disciplines.

They compete in their respective sports disciplines in which they strive for qualifying standards which guarantee a start in the $32^{\text {nd }}$ Summer Olympic or the $16^{\text {th }}$ Paralympic Games Tokyo 2020. Piotr Lisek has the best chance of winning a medal in Tokyo in pole vault, as well as the following disabled athletes: Anna Harkowska in cycling, Michał Gadowski in rowing, and Paulina Woźniak in swimming. Marcin Lewandowski - a titled European medallist in the $800 \mathrm{~m}$ race will probably compete in his fourth Summer Olympics Tokyo 2020 (he participated in 2008, 2012, and 2016) and this time will fight for the best place amongst the finalist in the $1,500 \mathrm{~m}$ race.
\end{abstract}

Key WOrlls students, graduates, Olympic athletes, Paralympic athletes, Olympic Games, Paralympics, University of Szczecin, Faculty of Physical Culture and Health Promotion

*as of 15 May 2019. 


\section{Introduction}

The Olympic idea had been known in Poland many years before the Polish Olympic Committee was established, and Polish athletes made their debut at the Olympic Games as a national team. Poland's historical circumstances and national captivity prevented Polish athletes from participating in the first Olympic Games of the modern era (in 1896, 1900 and 1904), but already in 1908 and in each subsequent Games, names of Polish athletes appeared amongst the participants of this most important competition in the world, although they did not always represent national colours. An analysis of the available literature showed that among the Olympic participants, there were many university students who successfully balanced sports and university education (Pawlak, 1983; Pawlak, 1988; Woltmann, Urban, 2007).

During the $125^{\text {th }}$ Session of the International Olympic Committee (IOC) in Buenos Aires, on September 7 , 2013, members of the Committee considered three potential host cities: Tokyo (Japan), Istanbul (Turkey), and Madrid (Spain); they chose the Japanese capital - Tokyo - as the host of the Summer Olympics in 2020. The $32^{\text {nd }}$ Olympic Games will be held from July 24 to August 9,2020 , while the $16^{\text {th }}$ Paralympic Games will take place from August 25 to September 6, 2020 (www.olimpjski.pl).

The dream of every sportsman is to participate in the largest international sports competitions, such as the Olympic Games organized every four years by the International Olympic Committee, the International Paralympic Committee in cooperation with the National Committees of the hosts of the next Games. 'In order to qualify for the Polish national team, certain qualification requirements in individual sports disciplines must be met (e.g. metric values, ranks at championships, ranking, as well as discretionary factors - the so-called 'wild card'), which enable participation in the Olympic and Paralympic Games' (Eider, Eider, 2012, p. 5).

Balancing sports activities at the highest world level with university education is a difficult - yet feasible - task. An example of this skilful balance are some graduates of the Higher Pedagogical School in Szczecin, University of Szczecin, majoring in Physical Education, who successfully graduated from the university with a defended Master's thesis while being active athletes. Among them are (chronologically listed) Olympians: Ireneusz Omięcki rowing, Marek Gawkowski - rowing, Marek Kolbowicz - rowing, Przemysław Stańczyk - swimming, Łukasz Chyła - athletics, Damian Zieliński - track cycling, Przemysław Czerwiński - athletics, Marcin Lewandowski - athletics, Konrad Wasielewski - rowing, Małgorzata Wojtyra - track cycling, Oskar Krupecki - swimming, Patryk Dobek athletics (Bachelor) and Paralympian Piotr Majka (Eider, Eider, 2015a; Eider, Eider, 2017; Tuszyński, Kurzyński, 2014).

The Faculty of Physical Culture and Health Promotion of the University of Szczecin (WKFiPZ US) is an entity whose dean's office, research, didactic and dean's staff are very favourable to students-athletes, including Olympians and Paralympians. Each of these athletes has an Individual Organization of Studies (IOS) or an Individual Plan and Program of Studies (IPPS), as determined by the Faculty Council' (Eider, 2017, pp. 136-137). This form of studying makes it possible to fulfil student duties to a large extent.

It should be emphasized that the IT techniques implemented at WKFiPZ US give employees and students a quick and modern access to national and world-wide databases of scientific information (Nadobnik, 2016). The systems operating at the department, e.g. intranet (internal university network) ensure efficient exchange of e-mails, and synchronizing meeting and consultations calendars. Modern information technology enables students - including athletes - to remotely use resources (via the Internet) made available by academic teachers in the form of teaching materials, lectures, multimedia presentations, etc. The computer network and individual 
employee accounts allow permanent contact with the department, which is used by the students-athletes to send final assignments and have individual consultations. Currently, studying athletes have better opportunities and conditions to obtain higher education compared to their peers from over a dozen years ago, when computer techniques were at the stage of development.

The purpose of this paper is:

a) to present current students of the Faculty of Physical Culture and Health Promotion of the University of Szczecin and a graduate of the Institute of Physical Culture of the Faculty of Natural Sciences at the University of Szczecin as potential candidates in their respective disciplines for the $32^{\text {nd }}$ Summer Olympic or $16^{\text {th }}$ Paralympic Games Tokyo 2020;

b) to show their sports achievements in previous Olympic and Paralympic Games;

c) to present indicators and qualification rules that the analysed athletes must follow to represent Poland in the Olympic and Paralympic Games Tokyo 2020;

d) to continue research in the field of broadly defined Olympism and Paralympism, including the participation of students and graduates of the University of Szczecin in the Summer Olympic or Paralympic Games.

\section{Materials and Methods}

The study involved a group of seven athletes, current students at the University of Szczecin, Faculty of Physical Culture and Health Promotion: Patryk Dobek, Michał Gadowski, Marcin Lewandowski, Piotr Lisek, Katarzyna Mądrowska, Paulina Woźniak, Krystian Zalewski and one graduate of the Institute of Physical Culture of the Faculty of Natural Sciences of the University of Szczecin, Anna Harkowska (Dokumentacja, 2019), (Table 1). Among subjects, there is Marcin Lewandowski, who graduated from the above-mentioned faculty in 2011, having received a master's degree in Physical Education (Eider, Eider, 2015a); currently, he is a first-cycle student of Public Health. In 2018, Patryk Dobek and Katarzyna Mądrowska completed first-cycle (Bachelor's) studies in Physical Education. They are currently continuing their studies at the second (Master's) level. The other athletes listed in Table 1 are: Michał Gadowski, Piotr Lisek, and Krystian Zalewski are first-cycle students of Physical Education, while Paulina Woźniak is a second-cycle student of Public Health (Dokumentacja, 2019). All of them are members of the national Polish team in their respective sport disciplines. The majority (62.5\%) are fully able (Patryk Dobek, Marcin Lewandowski, Piotr Lisek, Katarzyna Mądrowska, Krystian Zalewski), while the remaining 37.5\% are disabled athletes (Michał Gadowski, Anna Harkowska, Paulina Woźniak).

Table 1. Research material: students-athletes from the University of Szczecin

\begin{tabular}{|c|c|c|c|c|c|}
\hline \multirow{2}{*}{$\begin{array}{c}\text { First name and last } \\
\text { name }\end{array}$} & \multirow{2}{*}{ Age } & \multirow{2}{*}{ Major of studies } & \multicolumn{2}{|r|}{ Sports } & \multirow{2}{*}{$\begin{array}{c}\text { Currently represented } \\
\text { sports club }\end{array}$} \\
\hline & & & discipline & competition & \\
\hline 1 & 2 & 3 & 4 & 5 & 6 \\
\hline Patryk Dobek & 25 & Physical Education & Athletics & 400 metres hurdles & MKL Szczecin \\
\hline Michał Gadowski & 29 & Physical Education & Rowing (disabled) & mixed doubles TAMix2x, PR2 Mix & KSI 'Start' Szczecin \\
\hline Anna Harkowska & 39 & Physical Education & Cycling (disabled) & $\begin{array}{l}\text { - individual timed trial } \\
\text { - mass start race } \\
-3,000 \text { on the track }\end{array}$ & OKS 'Warmia i Mazury' \\
\hline Marcin Lewandowski & 32 & Public Health & Athletics & $\begin{array}{l}-800 m \\
-1,500 m\end{array}$ & WKS Zawisza Bydgoszcz \\
\hline Piotr Lisek & 27 & Physical Education & Athletics & pole vault & OSOT Szczecin \\
\hline
\end{tabular}




\begin{tabular}{|c|c|c|c|c|c|}
\hline 1 & 2 & 3 & 4 & 5 & 6 \\
\hline Katarzyna Mądrowska & 24 & Physical Education & wrestling & $62 \mathrm{~kg}$ & LKS Feniks Pesta Stargard \\
\hline Paulina Woźniak & 27 & Public Health & Swimming (disabled) & $\begin{array}{l}\text { - } 100 \mathrm{~m} \text { breaststroke } \\
\text { - } 100 \mathrm{~m} \text { butterfly stroke } \\
\text { - } 100 \mathrm{~m} \text { freestyle } \\
\text { - } 200 \mathrm{~m} \text { medley stroke }\end{array}$ & KSI 'Start' Szczecin \\
\hline Krystian Zalewski & 30 & Physical Education & Athletics & 3,000-meter steeplechase & UKS Barnim Goleniów \\
\hline
\end{tabular}

Source: Dokumentacja (2019); Eider, Eider (2012); Szaj (2016); Kaźmieraczak (2019a, 2019b); Mądrowska (2019).

The analysed research material was obtained from previous author's and co-author's papers, archival documentation of WKFiPZ US, written and oral reports of trainers, sports activists in Szczecin and employees of WKFiPZ US, www.wikipedia.pl. www.olimpijski.pl, www.paralympic.org.pl, and www.pzla.pl.

\section{Results}

Amongst the analysed athletes, only Katarzyna Mądrowska (wrestling) was not a participant of the Summer Games (Table 2). She has a chance to make her debut at the $32^{\text {nd }}$ Olympic Games Tokyo 2020. All the other athletes have already competed in the Olympic or Paralympic Games. The following athletes competed three times: Marcin Lewandowski, Paulina Woźniak (in 2008, 2012, 2016), (Eider, Eider, 2015b; www.wikipedia.pl).

In the group of athletes in question, the disabled sportswomen have won medal. Anna Harkowska has won a total of five silver medals at $14^{\text {th }}$ and $15^{\text {th }}$ Paralympic Games, in three Paralympic competitions: mass start race, individual timed trial, and $3000 \mathrm{~m}$ track race (Szaj, 2012, 2016). She won the Paralympic medals in 2012 and 2016, having already graduated from the IKF WNP US, as she had defended her Master's thesis on 'Trends of cross-country cycling in Poland and in the world' in 2005 (Dokumentacja, 2019). Paulina Woźniak has so far won two medals: silver and bronze in the $100 \mathrm{~m}$ competition in breaststroke at the $13^{\text {th }}$ and $14^{\text {th }}$ Paralympics Games (Woźniak, 2019).

It should be emphasized that two other athletes participated in the final competition (except for the mentioned: Anna Harkowska and Paulina Woźniak): Piotr Lisek, Marcin Lewandowski, as well as a disabled rower, Michał Gadowski (Table 2). In the 31st Summer Olympic Games in Rio de Janeiro 2016, a member of Ośrodek Szkolenia o Tyczce Szczecin , Piotr Lisek, took fourth place in the pole vault, while Marcin Lewandowski from the Wojskowy Klub Sportowy Zawisza Bydgoszcz had a $6^{\text {th }}$ place in the $800 \mathrm{~m}$ race. Michał Gadowski from the Klub Sportowy Inwalidów 'Start' Szczecin also won in Rio de Janeiro sixth place in mixed doubles.

Year 2019 and the first half of 2020 is very important in the training and preparation process of the analysed athletes, who represent a high level of sport skills, which allows them to obtain the qualification standards in their disciplines to guarantee their start in the $32^{\text {nd }}$ Summer Olympic Games or $16^{\text {th }}$ Paralympic Games Tokyo 2020. Every sportsman's dream is to be selected for the Polish Olympic or Paralympic team and successfully representing their country in the largest sports competition organized every four years. 


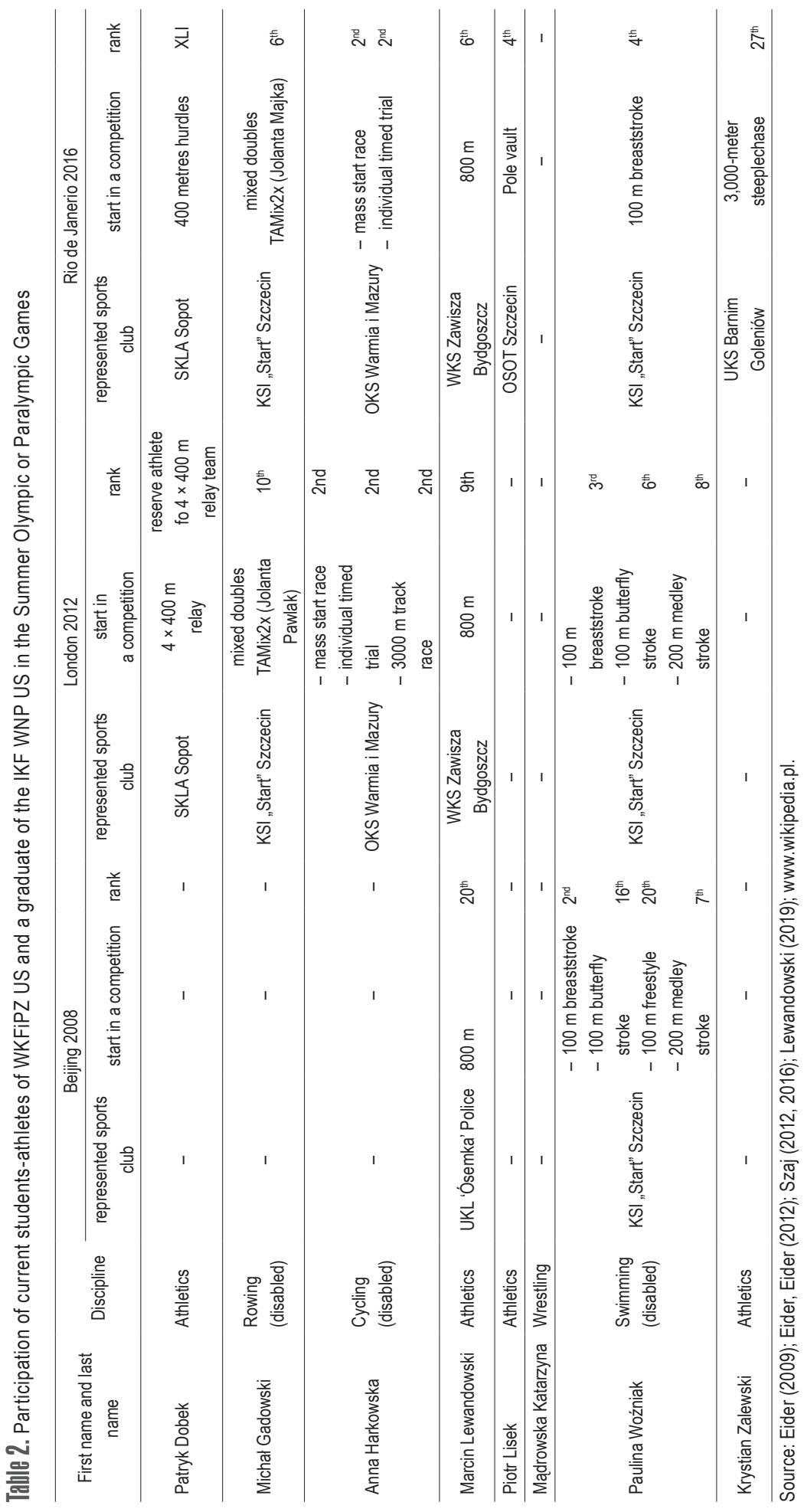




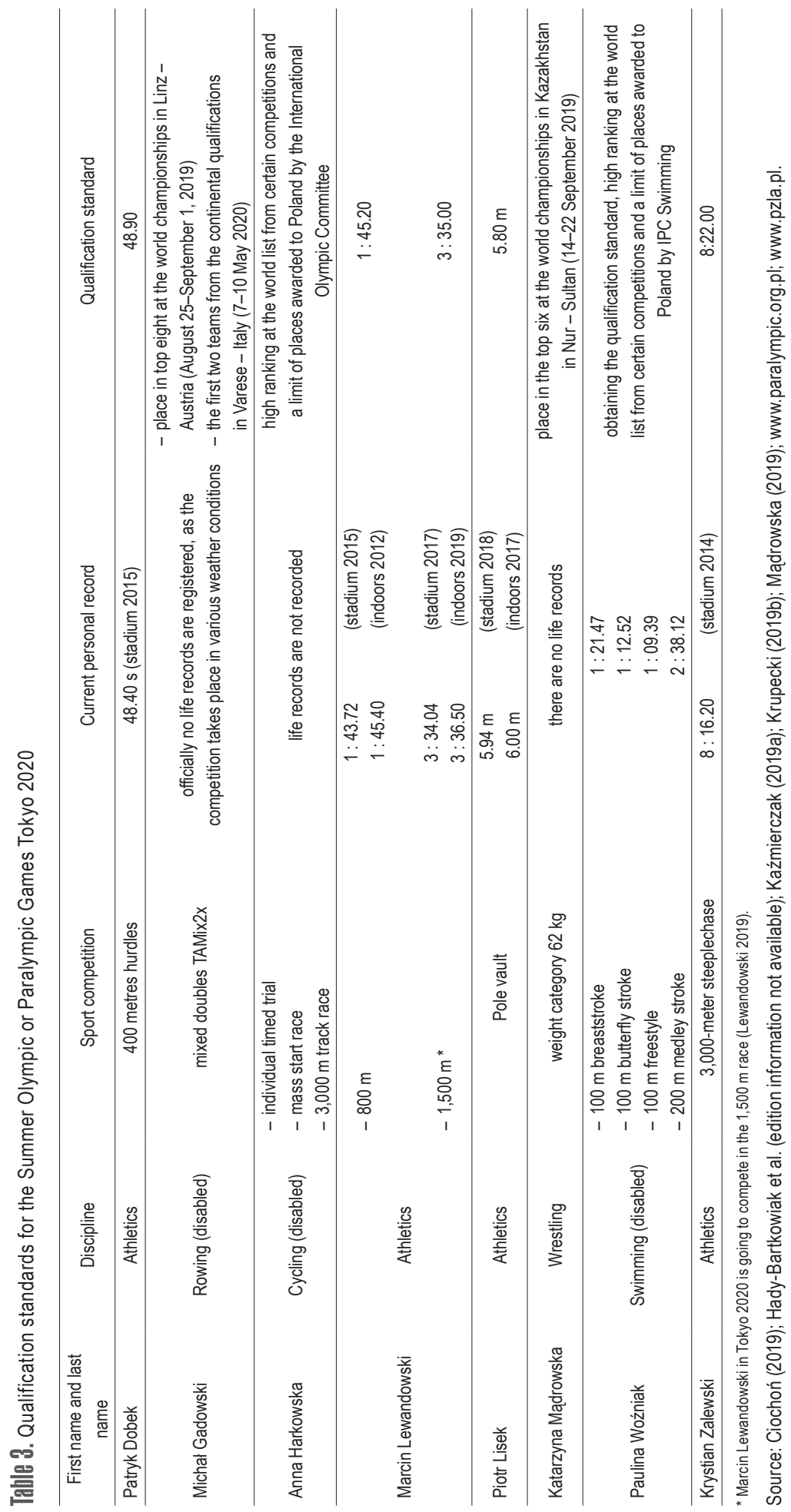


Table 3 lists the qualification standards which the analysed sportsmen must achieve in order to participate in the Tokyo sports competition. For athletics, the requirements are precisely defined by time results, while for pole vault by meters. The current life records of the analysed athletes are better than the applicable qualifying standards (Table 3), but worse than the results of the medallists of the 31 $1^{\text {st }}$ Olympic Games in Rio de Janeiro in 2016 (www. pzla.pl). In cycling, swimming and rowing of the disabled, as well as in wrestling, the sportsmen in question must first of all participate in the world championship and take one of top six or top eight ranks, as well as meet other qualifying standards (Ciochoń, 2019; Kaźmierczak, 2019a, Krupecki, 2019a).

It should be pointed out that Olympic and Paralympic teams are ultimately assigned by the Management Board of the Polish Olympic Committee and the Polish Paralympic Committee (following motions of the management boards of Polish sports associations); the teams include athletes, team leaders, members of the Olympic and Paralympic missions, medical mission, and guests of the team).

The analysed sportsmen in 2017-2019 (until May 15) competed in numerous competitions of various levels. Among others, they took places in top six, they won medals at national, European, and world championships (both at the stadium and indoors). Some of them are among the candidates to take a scored place, and even a medal during the planned Olympic or Paralympic Games Tokyo 2020.

\section{Discussion}

Qualifying for the Polish Olympic or Paralympic team, and then participating in the largest sports competition held every four years, is a great sports achievement for every sportsman. Majority of the national team members compete in their disciplines for a place in the finals, and a chance to win a medal.

In order to become an Olympian, or in the case of the disabled - a Paralympian - often many years of hard work are necessary, as well as subduing one's lifestyle completely to rigorous training, to be able to achieve a sports level which guarantees satisfying rivalry with the best sportsmen in the world. This aim is achieved only by few of the many athletes practicing Olympic disciplines (and less numerous group of Paralympic athletes).

Balancing studies with professional sports practice by students-athletes who are members of the national team, Olympic or Paralympic squad is often difficult - yet possible - to achieve. An example of this are previous graduates of Physical Education in Szczecin who, as students, participated in the largest sporting events, including the Summer Olympic and Paralympic Games (Eider, Eider, 2015b; Eider, Eider, 2017), as well as from other universities (Łuczak, 2015).

In 2007, an analysis was carried out related to a possibility of participation of eleven students-athletes from the IKF WNP US and one employee-athlete of the institute in the $29^{\text {th }}$ Summer Olympic Games and $13^{\text {th }}$ Paralympic Games Beijing 2008 (Eider, Eider, 2010). It turned out that as many as nine athletes obtained qualifying standards in their disciplines and were chosen for the Polish Olympic and Paralympic national team for Beijing. Among the team members of the IKF were Marek Kolbowicz and Konrad Wasielewski, who won gold medals in rowing quadruple sculls (with their mates, Michał Jeliński and Adam Korol), (Eider, 2009).

After the $30^{\text {th }}$ Olympic Games and $14^{\text {th }}$ Paralympic Games in London 2012, a study entitled 'Olympians and Paralympians of the West Pomeranian Voivodeship, London 2012' [Olimpijczycy i paraolimpijczycy województwa zachodniopomorskiego Londyn 2012] was published (Eider, Eider, 2012). The authors of this paper discussed, inter alia, sports achievements of the employee, students, and graduates of the University of Szczecin (Physical 
Education), who competed in London Olympics. Among the participants, there were five students, one employee and two graduates of WKFiPZ US.

In 2015, another scientific paper was published, in which the authors (Eider, Eider, 2015a) presented eight students-athletes from WKFiPZ US who worked on qualifying standards needed for their participation in the $31^{\text {st }}$ Olympic Games in Rio de Janeiro 2016. Ultimately, only three of them achieved the required sports results, and were able to participate in the Brazilian Olympic competition.

Sports achievements so far (including 2017-2019, unlit May 15) of current students-athletes and graduates indicate that all of them have a chance to obtain qualifying standards and participate in the $32^{\text {nd }}$ Olympic Games and the $16^{\text {th }}$ Paralympic Games in Tokyo. They are members of the national team. They participate in numerous national and foreign sports events. They work with the best trainers who carry out a long-term training process with them.

The presented research analyses on participation of students-athletes in the Summer Olympic or Paralympic Games confirm that many top-class sportsman also skilfully balance education with competitive sports. Through intense work, self-discipline, and enormous physical and intellectual effort, they achieve their sports and educational goals. It is advisable that after many hours of weekly and monthly training, the athlete's body be subjected to mental effort. It should be emphasized that an important supportive role is played by trainers who support them in their studies.

The management of the former IKF WNP US (currently WKFiPZ US), its academic teachers, and employees of the dean's office are very favourable to students-athletes, especially national team members, preparing for Olympic or Paralympic qualifications, participation in Summer Games or world/European championships. Every athlete has a so-called Individual Plan and Program of Studies, so that they can organize classes in a part-time mode, but they must demonstrate theoretical knowledge of subjects from the curriculum (Regulamin, 2019). Most of them fulfil their student duties and skilfully balance education with competitive sports. This is confirmed by the analysis of the number of IKF WNP US and WKFiPZ US student participation of in the $28^{\text {th }}-31^{\text {st }}$ Summer Olympic Games and $12^{\text {th }}-15^{\text {th }}$ Paralympic Games (Eider, 2004, 2009; Eider, Eider, 2012, 2015a, 2016b, 2017).

\section{Conclusions}

1. Among current WKFiPZ US students, there are seven students and one graduate of IKF WNP US who participate in certain sports competitions in which they obtain qualifying standards to guarantee their start in the $32^{\text {nd }}$ Summer Olympic Games or the $16^{\text {th }}$ Paralympic Games Tokyo 2020.

2. Piotr Lisek has the best chance of winning a medal in Tokyo in the pole vault, as well as the following disabled athletes: Michał Gadowski in rowing, Anna Harkowska in cycling, and Paulina Woźniak in swimming.

3. Marcin Lewandowski and Paulina Woźniak - these titled athletes will probably compete in their fourth Summer Olympic Games Tokyo 2020 (they participated in 2008, 2012, and 2016).

\section{Referenences}

\section{Archives}

Archival documentation of WKFiPZ US (dean's office, secretariat) (2019). WKFiPZ US.

Regulamin Indywidualnego Planu i Programu Studiów (IPPS) (2019). WKFiPZ US. 


\section{Printed publications}

Hady-Bartkowiak, K., Skupniewski, M., Kamiński, R., Schmidt, R., Marek, W., Kawecki, Z., Maźnicka-Maciaszek J., Dmeński G., Kwapiszewski K., Plinta, R., Kaźmierczak, T. (b. r.w.), Vademecum Sport Niepełnosprawnych Przepisy i Regulaminy. Warszawa: Oficyna Wydawnicza „Aba” Sp. z o.o.

Eider, J. (2004). Olimpijczycy i paraolimpijczycy klubów sportowych województwa zachodniopomorskiego - Ateny 2004. Szczecin: AMP Studio Paweł Majewski.

Eider, J. (2009). Olimpijczycy i paraolimpijczycy województwa zachodniopomorskiego - Pekin 2008. Szczecin: Wydawnictwo Naukowe Uniwersytetu Szczecińskiego.

Eider, J., Eider, P. (2010). Studenci Instytutu Kultury Fizycznej Uniwersytetu Szczecińskiego w gronie kandydatów na Igrzyska Olimpijskie i Paraolimpijskie - Pekin 2008. Zeszyty Naukowe Uniwersytetu Szczecińskiego, 570. Prace Instytutu Kultury Fizycznej, 25, 173-183.

Eider, J., Eider, P. (2012). Olimpijczycy i paraolimpijczycy województwa zachodniopomorskiego Londyn 2012. Szczecin: Zapol.

Eider, J., Eider, P. (2015a). Olimpijczycy-absolwenci Wyższej Szkoły Pedagogicznej w Szczecinie, Uniwersytetu Szczecińskiego, kierunku studiów wychowanie fizyczne. In: J. Eider (ed.), Wybrane zagadnienia olimpijskie w teorii i praktyce (pp. 121-136). Szczecin: Wydawnictwo Naukowe Uniwersytetu Szczecińskiego,

Eider, J., Eider, P. (2015b). Olimpijczycy szczecińskich klubów sportowych na igrzyskach XXVIII-XXX Olimpiady Ateny-Pekin-Londyn. In: J. Eider (ed.), Ruch olimpijski w teorii i praktyce (pp. 83-96). Szczecin: Wydawnictwo Naukowe Uniwersytetu Szczecińskiego

Eider, J., (2017). Wydział Kultury Fizycznej i Promocji Zdrowia Uniwersytetu Szczecińskiego w latach 2011-2016. Szczecin: Wydawnictwo Naukowe Uniwersytetu Szczecińskiego.

Eider, J., Eider, P. (2017). Problematyka olimpijska i paraolimpijska w działalności Wydziału Kultury Fizycznej i Promocji Zdrowia Uniwersytetu Szczecińskiego. Szczecin: Wydawnictwo Naukowe Uniwersytetu Szczecińskiego.

Nadobnik, J. (2016). The use of drones in organizing the Olimpic Games. Handel Wewnętrzny, 365, 288-299.

Łuczak, M. (2015). Medaliści igrzysk olimpijskich i paraolimpijskich - absolwenci Akademii Wychowania Fizycznego w Poznaniu. In: J. Eider (ed.), Ruch olimpijski w teorii i praktyce (pp. 97-108). Szczecin: Wydawnictwo Naukowe Uniwersytetu Szczecińskiego.

Pawlak, A. (1983). Status polskich olimpijczyków po zakończeniu kariery sportowej. Warszawa: Wydawnictwo Akademii Wychowania Fizycznego w Warszawie.

Pawlak, A. (1988). Problemy łączenia kariery zawodniczej z nauką. Almanach PKOI II 1987/1988, 2, 123-129.

Szaj, R. (2012). Letnie Igrzyska Paraolimpijskie Londyn 2012. Elblag: Wydawnictwo Uran.

Szaj, R. (2016). Medaliści Letnich Igrzysk Paraolimpijskich Rio de Janeiro 2016. Elblag: R. Sz. Polska Fundacja Paraolimpijska. Elbląg-Truszczyny.

Tuszyński, B., Kurzyński, H. (2014). Leksykon olimpijczyków polskich. Od Chamonix i Paryża do Soczi 1924-2014. Warszawa: Polski Komitet Olimpijski.

Woltmann, B., Urban, R. (eds.) (2007). Ruch olimpijski na ziemi gorzowskiej. Gorzów Wlkp.: Polskie Towarzystwo Naukowe Kultury Fizycznej.

\section{Written reports}

Kaźmierczak Tomasz, Szczecin 2019a.

Krupecki Krzysztof, Szczecin 2019a.

Lewandowski Tomasz, Police 2019.

Mądrowska Katarzyna, Stargard, 2019.

\section{Oral reports}

Ciochoń Jacek, Szczecin 2019.

Kaźmierczak Tomasz, Szczecin 2019b.

Krupecki Krzysztof, Szczecin 2019b.

Woźniak Paulina, Szczecin 2019 


\section{Internet sources}

www.wikipedia.pl.

www.olimpijski.pl.

www.paralympic.org.pl.

www.pzla.pl.

Cite this article aS: Eider, J. (2019). Students of the University of Szczecin as Candidates for the Olympic or Paralympic Games Tokyo 2020. Central European Journal of Sport Sciences and Medicine, 2 (26), 67-76. DOI: 10.18276/cej.2019.2-07. 